\title{
Histological, ultrastructural, and in situ hybridization study on enlarged cells in grouper Epinephelus hybrids infected by grouper iridovirus in Taiwan (TGIV)
}

\author{
Chia-Ben Chao ${ }^{1,4, *}$, Chun-Yao Chen ${ }^{2}$, Yueh-Yen Lai ${ }^{3}$, Chan-Shing Lin ${ }^{3}$, \\ Hung-Tu Huang ${ }^{4}$ \\ ${ }^{1}$ Institute for Animal Disease Prevention and Control, Kaohsiung, Taiwan 830, ROC \\ ${ }^{2}$ Department of Life Science, Tzu-Chi University, Hualien, Taiwan 970, ROC \\ ${ }^{3}$ Department of Marine Resources, National Sun Yat-Sen University, Kaohsiung, Taiwan 804, ROC \\ ${ }^{4}$ Department of Biological Sciences, National Sun Yat-Sen University, Kaohsiung, Taiwan 804, ROC
}

\begin{abstract}
Grouper iridovirus in Taiwan (TGIV) infection in the Epinephelus hybrid is a major problem in the grouper industry. ATPase gene sequences indicate that this virus is closely related to cell hypertrophy iridoviruses. Histologically, the appearance of basophilic or eosinophilic enlarged cells in internal organs is the most characteristic feature of this disease. These cells are acidphosphatase positive and are able to phagocytose injected carbon particles. In our study, TGIV infection inhibited normal phagocytic ability in these cells in vivo after $4 \mathrm{~d}$ post-infection (p.i.) but not before $2 \mathrm{~d}$ p.i. Their staining properties and phagocytic ability suggested a monocyte origin of enlarged cells, which appeared in high numbers in the trunk kidney, head kidney, spleen and gill. After infection, the enlarged cells first appeared in the spleen, with an abundance peak at $64 \mathrm{~h}$ p.i. (Peak 1); at 120 h p.i., a second peak (Peak 2) occurred in the spleen, head kidney, trunk kidney and gill. Lower numbers of enlarged cells were observed in the liver, muscle, heart, eye, intestine, but no enlarged cells were found in the brain. A TGIV-specific DNA probe labeled most of the basophilic but not eosinophilic enlarged cells. Nuclei of infected cells were labeled during an early stage of the infection; at later stages, both nuclei and cytoplasms were labeled. Ultrastructurally, heterochromatins of the infected cells were marginated or aggregated to one side of the nuclei during the early stages of infection. Damage and rupture of the nuclear membrane started before formation of the viromatrix. Capsids were assembled in ring-shaped or disc-shaped structures. Bullet-shaped electron-dense material was present near the incomplete virus particles, and is speculated to be inserted into the capsids later.
\end{abstract}

KEY WORDS: In situ hybridization · Enlarged cell · TGIV · Morphogenesis · Cell hypertrophy iridovirus

\section{INTRODUCTION}

In the aquaculture industry, members of the family Iridoviridae are an emerging group of fish pathogens. Since the mid-1980s, systemic iridovirus infections associated with high mortality $(90 \%)$ have occurred among cultured freshwater and saltwater fish species from wide geographical regions including Africa, the Americas, Asia, Australia and Europe. They can be divided into 2 type-groups by characteristic pathological features. The first group includes the European catfish iridovirus $(E C V)$, the sheatfish iridovirus (ESV), and the epizootic hematopoietic necrosis virus (EHNV), which cause severe necrosis in hematopoietic 
tissue, and are classified as Ranavirus. Another type of iridovirus infection emerged in the early 1990s; this type cause less necrosis of the hematopoietic tissue than the first group, but, in addition to hematopoietic necrosis, causes numerous enlarged cells in many other tissues. This second group includes the red sea bream iridovirus (RSIV), sea bass iridovirus (SBIV), African lampeye iridovirus (ALIV), grouper iridovirus (GIV) found in southeast Asia, and the infectious spleen and kidney necrosis iridovirus (ISKNV) (Miyata et al. 1997, He et al. 2000). Grouper iridovirus in Taiwan (TGIV) was first reported in 1997 (Chao \& Pang 1997), and has histological characteristics similar to the second group. He et al. (2001) compared ATPase, DNA polymerase and RNA polymerase genes of selected members of Iridoviridae and suggested that RSIV, SBIV, ALIV, GIV and ISKNV may belong to a new genus, and tentatively referred to them as 'cell hypertrophy iridoviruses'. A research group led by $\mathrm{T}$. Miyazaki also proposed the definition tropical iridovirus or 'Tropivirus' for these viruses (Sudthongkong et al. 2002b). In 2003, V. G. Chinchar et al. (pers. comm.) proposed a new genus, Megalocytivirus, to the International Committee on Taxonomy of Viruses (ICTV) which recognizes TGIV as a member of this genus. In this proposed classification system, 2 subfamilies were established; Invertiridovirinae for the invertebrate iridoviruses Iridovirus and Chloriridovirus; and Chordiridovirinae for the vertebrate iridoviruses Ranavirus, Lymphocystivirus, and Megalocytivirus.

Grouper culture in Taiwan and southeast Asia is important because of the high market value of these fish, but 2 major viral diseases, viral nervous necrosis (VNN) caused by a nodavirus and TGIV infection, have caused high economical loss for many years. Because VNN affects mostly larvae and fingerlings its impact is not as devastating as that of TGIV infection, which can also affect larger individuals. Mortality generally continues for weeks, and the accumulated mortality in even a well-managed farm can still be high (60 to $80 \%$ in juveniles and 10 to $30 \%$ in larger fish). We have developed a sensitive nested PCR procedure to detect TGIV, and an in situ hybridization method for labeling virus-containing cells (Chao et al. 2002). However, the nature of the main histological feature of this disease, enlarged cells, is still largely unknown. In this study, using ATPase gene sequences we present the first molecular evidence to show that TGIV is closely related to other members of Megalocytivirus. By means of in situ hybridization, we have examined the distribution kinetics of enlarged cells during the course of infection and describe the ultrastructure of the infected cells and the morphogenesis of TGIV.

\section{MATERIALS AND METHODS}

Viral strain. Virus Strain 86059 was collected from naturally infected groupers, Epinephelus hybrid, in Yung-Ann, Kaohsiung, southern Taiwan. This strain caused a typical severe outbreak in hybrid groupers, and therefore was used in sequence determination as well as all challenge experiments. Since there is still no reliable cell line that can be used for isolation and propagation, the virus was passed in vivo through naïve hybrid groupers, and tissues collected from infected fish were used as the source of the pathogen.

The parent species of the host grouper was not identifiable, due to the extensive cross-breeding of Epinephelus malabaricus with other wild-caught grouper species, a common practice over the past $15 \mathrm{yr}$.

ATPase gene sequence determination. The ATPase gene was amplified by the primer set 3-F/3-R (Kurita et al. 1998). After revealing on $1.5 \%$ agarose gel, the PCR product was recovered from the gel and cloned into a pGEM-T vector system (Promega Corporation, Madison, Wisconsin), and then transfected into Escherichia coli Strain DH5 $\alpha$. DNA sequences from 3 selected clones were determined by an ABI Prism 377-96 DNA sequencer (Perkin-Elmer, Wellesley, Massachusetts) with aa ABI Prism big dye terminator cycle sequencing ready reaction kit. The determined sequence was deposited in GenBank (Accession No. AAL68652). Abbreviations and accession numbers of other sequences used in this study are: ALIV, BAA96408: African lampeye iridovirus; CIV, T03048: chilo iridescent virus; FV3, S27907: frog virus 3; GIV, BAA96407: grouper iridovirus (Epinephelus malabaricus, Thailand); ISKNV, NP_612345: infectious spleen and kidney necrosis virus; IV6, NP_149538: invertebrate iridescent virus 6 075L; LCDV, NP_078656: lymphocystis disease virus 1; LMBIV, AAL68654: largemouth bass iridovirus; RSIV, BAA28670: red sea bream iridovirus; RTRV, AF511654_1: Rana tigrina ranavirus; SBIV, BAA96406: sea bass iridovirus; SFAV1, CAC84470: Spodoptera frugiperda ascovirus 1; SPIV, AAL68653: giant sea perch iridovirus. SFAV1, an ascovirus, was used as an outgroup. Both LMBIV and SPIV were found in Taiwan (Chao et al. 2002) and caused diseases similar to those arising from TGIV and RSIV infections.

ClustalX software (Thompson et al. 1997) version 1.81 was used for multiple alignment of the sequences and generation of the bootstrap neighborhood-joint tree (1000 bootstrap trials). The phylogenetic tree was displayed using TreeView Version 1.6.5 (available from Roderic D. M. Page at http://taxonomy.zoology. gla.ac.uk/rod/rod.html).

Experimental infection. Naïve healthy hybrid groupers were obtained from a local farm in YungAnn, Kaohsiung, Taiwan. To ensure that the fish had 
not been exposed previously to TGIV, only those individuals that satisfied the following criteria were used: (1) survival rate from larvae to juvenile stage exceeded $95 \%$ with no signs of disease; (2) during the 2 mo acclimation period in the laboratory, no signs of infection were observed; (3) CY15n-F, R and RY16-F, R primer sets (Chao et al. 2002) detected no signs of infection.

Batches of sixty 50 to $60 \mathrm{~g}$ fish were kept in $2000 \mathrm{l}$ fiber-glass tanks. Water was changed daily with ambient seawater, and dissolved oxygen (DO), nitrite $\left(\mathrm{NO}_{2}\right.$ $\mathrm{N})$, total ammonia $\left(\mathrm{NH}_{3}\right)$, and $\mathrm{pH}$ were monitored regularly. During the experimental period, DO readings were between 6.0 to $7.5 \mathrm{ppm}, \mathrm{NO}_{2}-\mathrm{N}$ readings were below $0.06 \mathrm{ppm}, \mathrm{NO}_{3}$ readings were below $0.08 \mathrm{ppm}$, and $\mathrm{pH}$ values were between 8.2 and 8.5 . Water salinity was between 3.0 and $3.4 \%$. All measurements were made around 10:00 h. During the experimental period there were no signs of disease other than those expected from experimental challenge. Test fish were challenged by intra-muscular (i.m.) injection of $0.1 \mathrm{ml}$ of a $0.45 \mu \mathrm{m}$-filtered pooled tissue-homogenate from several proven infected fish as described by (Chao et al. (2002). The inoculum was injected into the musculature $1 \mathrm{~cm}$ below the first fin ray of the dorsal fin. Control fish were maintained under similar conditions in a separate tank.

Indian ink injection and acid phosphatase staining. We used Indian ink injection to reveal phagocytic activity of enlarged cells (Li et al. 2001). Healthy fish were injected with Indian ink (Chroma-Gesellschaft, Kongen, Germany). The Indian ink was diluted 1:5 by $0.1 \mathrm{M}$ phosphate buffer ( $\mathrm{pH} 7.3$ ), and $0.85 \mu \mathrm{m}$-filtered before injection into the fish. The volume injected was $600 \mu \mathrm{l}_{100 \mathrm{~g}^{-1} \text { fish. }}$

Injection was performed at 0,2 , or $4 \mathrm{~d}$ p.i., and fish were sacrificed at $6 \mathrm{~d}$ p.i. Two routes, intraperitoneal (i.p.) and i.m., were attempted. i.p. injection of Indian ink was used for i.p.-infected fish, and i.m. injection for i.m.-challenged fish. In the i.m. group, the Indian ink was injected into the trunk musculature on the left, and in the i.m. group the virus suspension was injected into the trunk musculature on the right.

During necropsy, the gills were examined on wet mounts to identify enlarged cells containing carbon particles. Biopsies of gills were embedded in Shandon Cryomatrix (Thermo Electron Corporation, Waltham, Massachusetts) and 5 to $6 \mu \mathrm{m}$-thick sections were cut with a Shandon Microtome Model 5030. The sections were fixed and stained with a Sigma acid phosphatase leukocyte staining kit (St. Louis, Missouri) following the manufacturer's instruction.

Sampling. We sampled 3 fish each at $0,24,32,40,48$, $56,64,72,80,88,96,104,112,120,128,136,144,152$, and $160 \mathrm{~h}$ p.i. During necropsy, gill, liver, spleen, trunk kidney, head kidney, heart, eye, brain, intestine, and muscle around the injection site were collected from each fish. These samples were fixed in neutral buffered formalin solution $(10 \%$ formalin, $33 \mathrm{mM}$ $\mathrm{NaH}_{2} \mathrm{PO}_{4}, 45 \mathrm{mM} \mathrm{Na}_{2} \mathrm{HPO}_{4}$ ) for at least $24 \mathrm{~h}$. The tissues were then dehydrated, embedded in paraffin, and cut into approximately 3 to $4 \mu \mathrm{m}$ thick sections on a rotary microtome (HM330, Carl Zeiss, Oberkochen, Germany). The sections were stained with hematoxylin and eosin (H\&E stain, Merck, Whitehouse Station, New Jersey) for histological evaluation. Serial sections from the same tissue blocks were retained and placed onto $2 \%$ silane pretreated slides for further in situ hybridization (Nuove et al. 1991).

In situ hybridization. Non-radioactive DNA probes were prepared by PCR amplification, using digoxigenin (PCR DIG labeling mix; Roche Molecular Biochemicals, Indianapolis, IN, USA). The primers used (CY15n-F and CY15n-R) are specific to TGIV (Chao et al. 2002). The procedure for in situ hybridization of labeled DNA probes was previously described by Chang et al. (1996). The sequence of this 1339 bp DNA probe (Genbank Accession No. AF462341) corresponds to the ISKNV genome (NC_003494) bases 37458 to 38796.

We serially sectioned the tissues and used them for both standard H\&E staining and in situ hybridization. The H\&E-stained sections were used to count and identify basophilic and eosinophilic enlarged cells, and the in situ hybridization-labeled sections were used to quantify the virus-containing cells.

Electron microscopy. Hybrid grouper tissue samples collected from both natural outbreaks and artificial challenges were examined by electron microscopy. Biopsies of spleen and head kidney were collected from each fish. These tissues were cut into approximately $1 \mathrm{~mm}^{3}$ cubes, and fixed in $2.5 \%$ glutaraldehyde in $0.1 \mathrm{M}$ phosphate buffer, $\mathrm{pH} 7.3$, for $2 \mathrm{~h}$. The samples were then washed in phosphate buffer and finally post-fixed in $1 \%$ osmium tetroxide for $1 \mathrm{~h}$. The fixed tissues were dehydrated in a graded series of ethanol and embedded in Spurr's resin. Ultrathin sections were prepared with an ultramicrotome (Leica Ultracut $\mathrm{R}$, Leica Microsystems, Wetzlar, Germany), and subsequently double-stained with uranyl acetate and lead citrate and observed at $80 \mathrm{kV}$ with a Jeol TEM-1200EX (Akishima, Japan).

\section{RESULTS}

A 1208 bp fragment was amplified by PCR from TGIV-infected grouper tissue samples using RSIV ATPase-specific primers. The sequence obtained from this gene is very closely related to that of the ISKNV, with $99.9 \%$ identity $(1207 / 1208)$. The deduced amino acid sequence (239 amino acids) was compared to that 


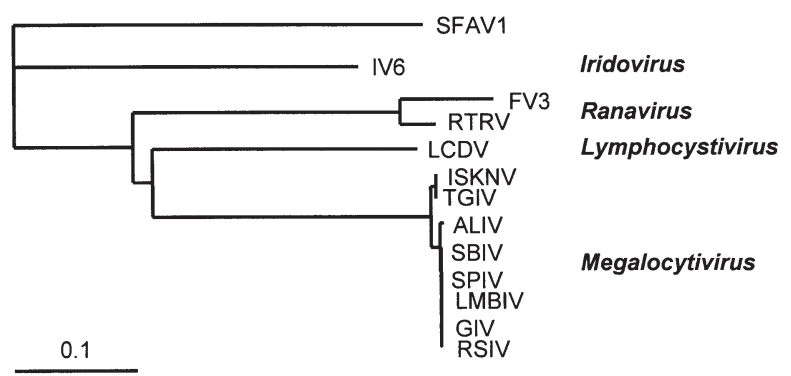

Fig. 1. Phylogenetic relationship between grouper iridovirus in Taiwan (TGIV) and other selected members of Iridoviridae revealed by amino acid sequences of ATPase. The tree indicates that TGIV is closely related to other known cell hypertrophy iridoviruses, including RSIV, ALIV, GIV, SBIV, and ISKNV. ALIV: African lampeye iridovirus; CIV: Chilo iridescent virus; FV3: Frog Virus 3; GIV: Grouper iridovirus (Epinephelus malabaricus, Thailand); ISKNV: infectious spleen and kidney necrosis virus; IV6: invertebrate iridescent virus 6 075L; LCDV: lymphocystis disease virus 1; LMBIV: largemouth bass iridovirus; RSIV: red sea bream iridovirus; RTRV: Rana tigrina ranavirus; SBIV: sea bass iridovirus; SFAV1: Spodoptera frugiperda ascovirus 1; SPIV: giant sea perch iridovirus; TGIV: grouper iridovirus in Taiwan. SFAV1, an ascovirus, is used as outgroup. Scale bar shows dissimilarity in sequences $(1=100 \%)$

from selected members of Iridoviridae currently available in Genbank (Fig. 1). TGIV clustered with all known cell hypertrophy iridoviruses, including RSIV, ALIV, GIV, SBIV and ISKNV. TGIV and ISKNV form a separate group from ALIV, GIV, RSIV, and SBIV, which also form a separate group. Both groups are more dis- tant from other iridoviruses, including Ranavirus (FV3 and RTRV), Lymphocystivirus (LCDV1) and Iridovirus (CIV). This sequence data provides molecular evidence to support the classification of TGIV as a Megalocytivirus.

Enlarged cells were visible in gill wet-mounts (Fig. 2A). Most of the enlarged cells observed were acid-phosphatase positive (Fig. 2B), suggesting that they were probably macrophages. We used Indian ink infection to examine the phagocytic ability of these enlarged cells. Enlarged cells containing black particles were observed in gills collected $6 \mathrm{~d}$ p.i. after receiving an Indian ink injection at $0 \mathrm{~d}$ (right after infection) or $2 \mathrm{~d}$ p.i. injection of viral preparation (Fig. $2 \mathrm{C})$, indicating that these cells were abnormal macrophages. When the fish received Indian ink injection at $4 \mathrm{~d}$ p.i, the enlarged cells contain no carbon particles, suggesting that during the first $2 \mathrm{~d}$ of infection the macrophages were still able to move into the injection sites and phagocytose the particles. This ability was largely inhibited at $4 \mathrm{~d}$ p.i.

These cells were widely distributed in most internal organs (Fig. 3), and were either eosinophilic or basophilic, as revealed by H\&E staining. The nuclei, when visible, were displaced to one side. The enlarged cells were present in high numbers in 4 major sites: the trunk kidney, head kidney, spleen, and gills (Fig. 4). Smaller numbers were present in the heart, muscle, and liver, and very few or none in the intestine, eye, or brain (Fig. 5). The head kidney and spleen seem to be the major target organs of the TGIV infection. The first
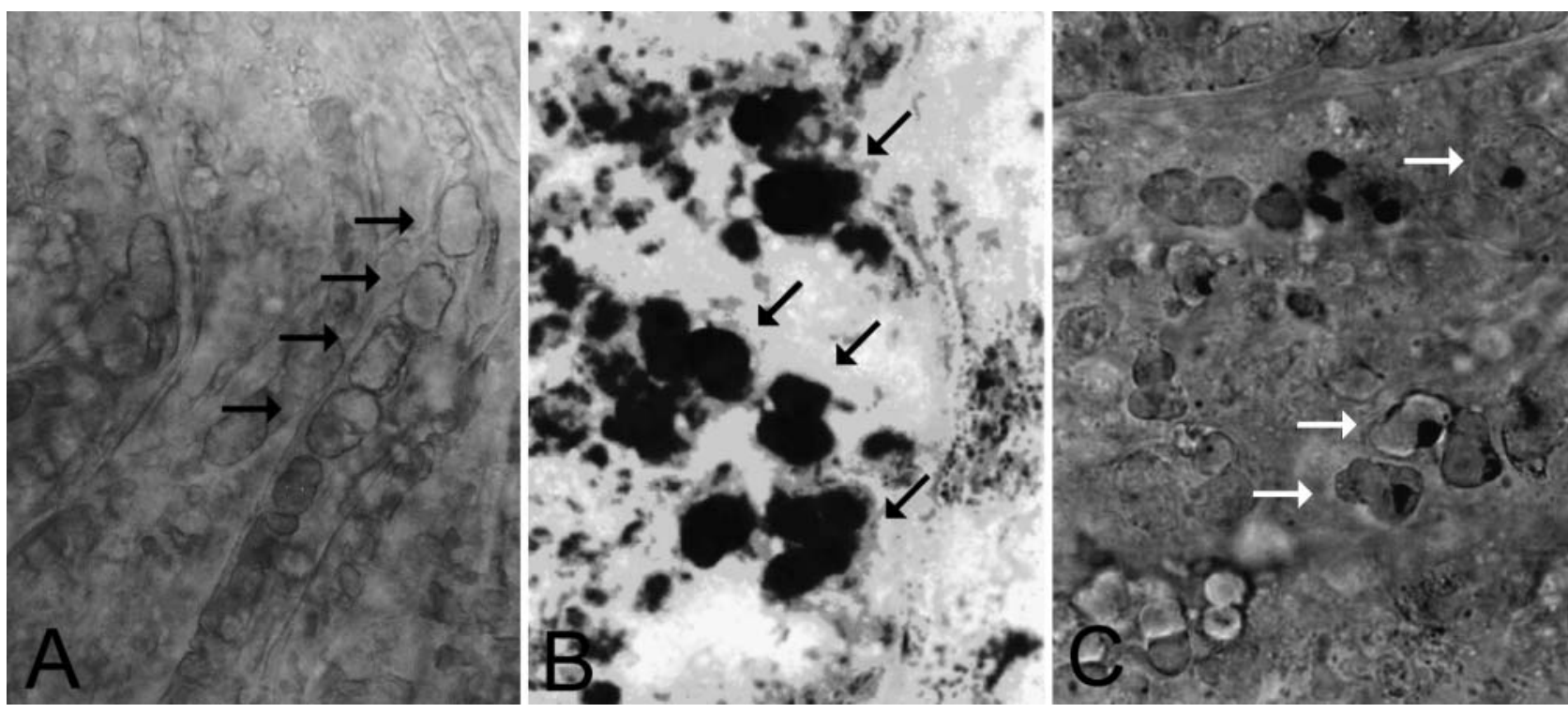

Fig. 2. Epinephelus hybrid. Wet mounts of gills collected $5 \mathrm{~d}$ p.i. after TGIV challenge, showing presence of enlarged cells (arrows). (A) Numerous enlarged cells in secondary lamellae; (B) cryosection of gill, showing that enlarged cells are acidphosphatase positive; (C) gill of grouper that received TGIV challenge and Indian ink injection on same day; the enlarged cells

contained intracytoplasmic black particles, suggesting that they were phagocytic, and that they are infected macrophages 


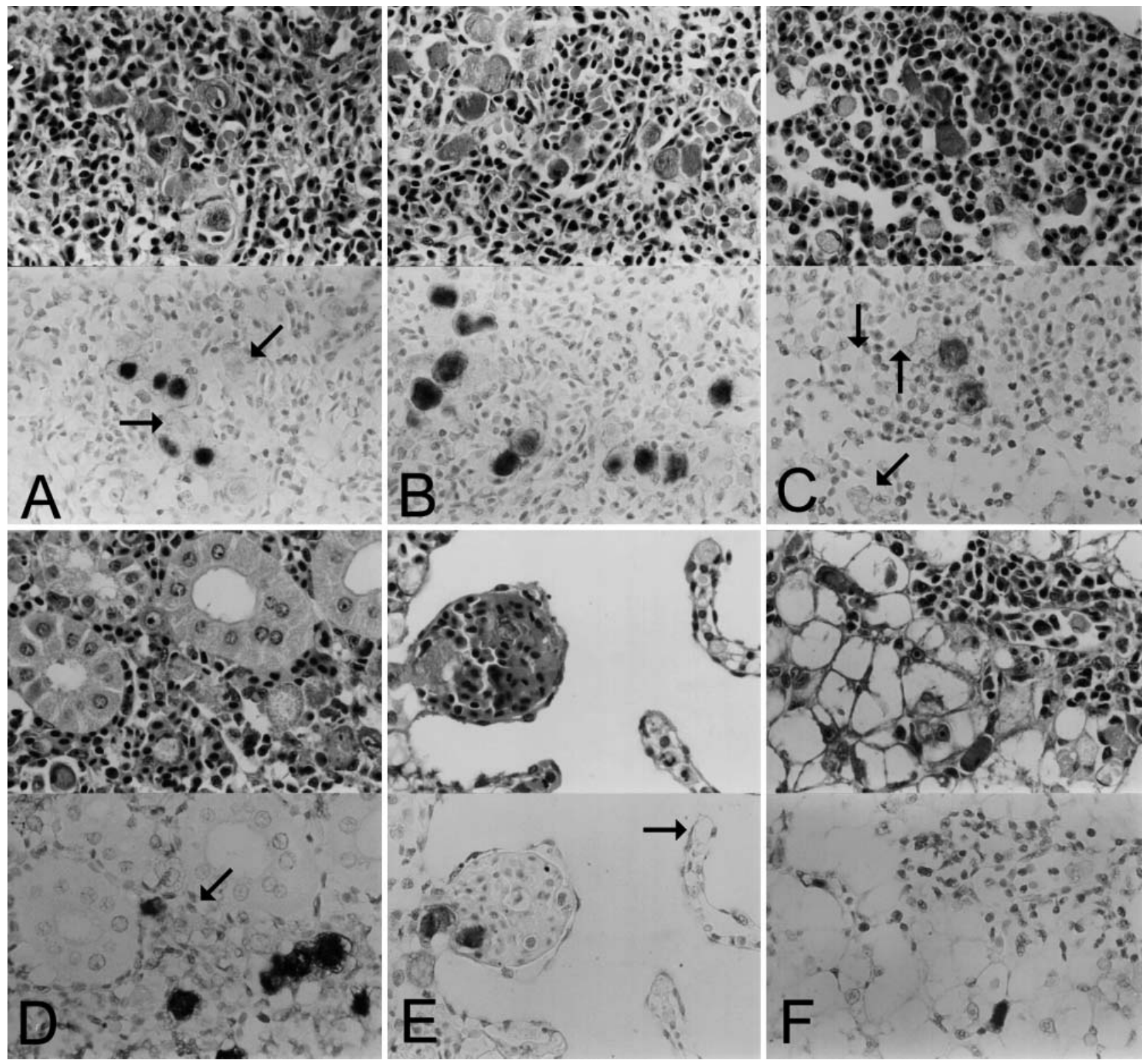

Fig. 3. Epinephelus hybrid. Enlarged cells in different organs after TGIV challenge. Serial sections stained by hematoxylin and eosin (upper portions of micrographs) or in situ hybridization (lower portions of micrographs). TGIV-specific probe CY15 was applied during in situ hybridization. (A) Spleen $64 \mathrm{~h}$ post-infection (p.i.); only basophilic enlarged cells were seen in spleen; the probe concentrated in the nuclei of basophilic enlarged cells, no other cell type was labeled; some basophilic enlarged cells with inclusion bodies were not labeled (arrows). (B) Spleen $72 \mathrm{~h}$ p.i.; probes labeled both nuclei and cytoplasm of basophilic enlarged cells. (C) Spleen $144 \mathrm{~h}$ p.i.; basophilic and eosinophilic enlarged cells were both present; probe only labeled basophilic enlarged cells, not eosinophilic enlarged cells (arrows). (D) Trunk kidney, 144 h p.i.; (E) Gill 144 h p.i.; (F) Liver 120 h p.i. The magnification is $\times 500$

increase in abundance of enlarged cells was in the spleen at $64 \mathrm{~h}$ p.i.; and a second peak followed at $120 \mathrm{~h}$ p.i. in the spleen, trunk kidney, head kidney and gill. The number of basophilic enlarged cells fluctuated parallel to the number of total enlarged cells before $134 \mathrm{~h}$ p.i.; after this time they declined, although the total number of enlarged cells did not. In the gills, the number of total enlarged cells started to increase after $88 \mathrm{~h}$ p.i., and the number of basophilic enlarged cells was low, with only a small increase at $144 \mathrm{~h}$ p.i.

In situ hybridization successfully showed the distribution and kinetics of the viral DNA-containing cells. The numbers of labeled cells and basophilic cells were very similar in all sections examined (Figs. 4 \& 5). 

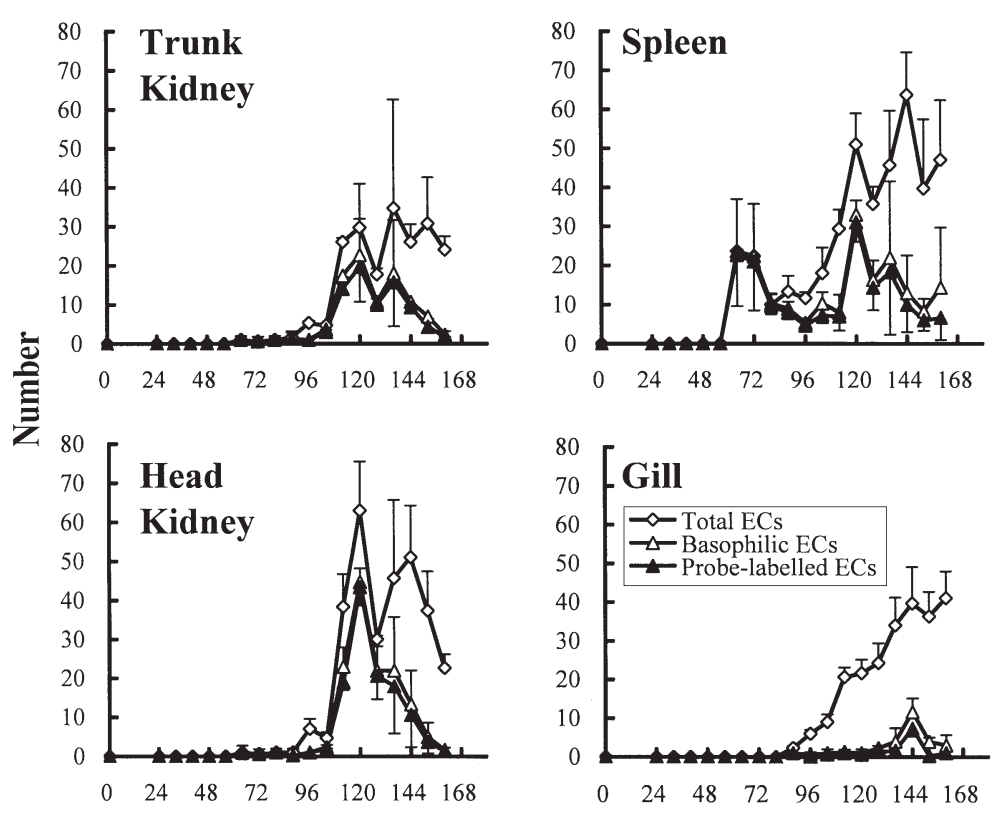

Time (h)

Fig. 4. Epinephelus hybrid. Kinetics of total enlarged cells, basophilic enlarged cells, and enlarged cells labeled by in situ hybridization in trunk kidney, head kidney, spleen, and gill during course of TGIV infection. Data are cell counts for $500 \times 500 \mu \mathrm{m}$ area. EC: enlarged cell

Because serial sections were used in H\&E and in situ hybridization, we could identify most labeled enlarged cells in the parallel H\&E stained sections. All labeled cells were basophilic, and eosinophilic enlarged cells were never found labeled. This indicates that the basophilic, not the eosinophilic enlarged cells, are virus-containing. No other cell type was labeled in the tissues of infected fish. At $64 \mathrm{~h}$ p.i., the probes concentrated only in the nuclei of infected cells (Fig. 3A), whereas both nuclei and cytoplasm were labeled at $72 \mathrm{~h}$ p.i. (Fig. 3B, C). Enlarged cells with prominent intra-nuclear inclusion bodies had lower affinity to the probe and were usually not stained (Fig. 3A).

At the injection site, inflammation with mononuclear cell infiltration was noted at $24 \mathrm{~h}$ p.i. Enlarged cells were first found at $40 \mathrm{~h}$ p.i. at the injection site, and some of these that contained intra-nuclear inclusion bodies with epithelioid cells appeared in the same region. At $72 \mathrm{~h}$ p.i., inflammation, hyaline degeneration of the skeletal muscle, and connective tissue repairs were seen in the muscle near the injection site.
Enlarged cells were first seen in the spleen at $64 \mathrm{~h}$ p.i. (Fig. 3A). At this time, only basophilic enlarged cells were observed. The nuclei of some cells increased significantly in size, to twice the diameter of a normal nucleus in some cases. Intra-nuclear inclusion bodies were seen in some enlarged cells. The DNA probes only labeled the nuclei and not the cytoplasm. A few basophilic enlarged cells were not labeled, and most of the unlabeled cells had intra-nuclear inclusion bodies. At $72 \mathrm{~h}$ p.i., only the basophilic enlarged cells were still present in the spleen, and the DNA probes labeled both nuclei and cytoplasm of the enlarged cells. The numbers of enlarged cells increased from $64 \mathrm{~h}$ p.i., but the proportion of enlarged cells with intra-nuclear inclusion bodies decreased. Most of the enlarged cells were eosinophilic at $144 \mathrm{~h} \mathrm{p}$.i., and necrosis of the splenic cells was evident.

Significant numbers of enlarged cells were found in both the trunk kidney and head kidney, (Fig. 3C, D, E). At 120 h p.i., a dramatic increase in the number of enlarged cells was seen in both kidneys, especially in the head kidney. The hematopoietic tissues were largely replaced by enlarged cells. Other tis-
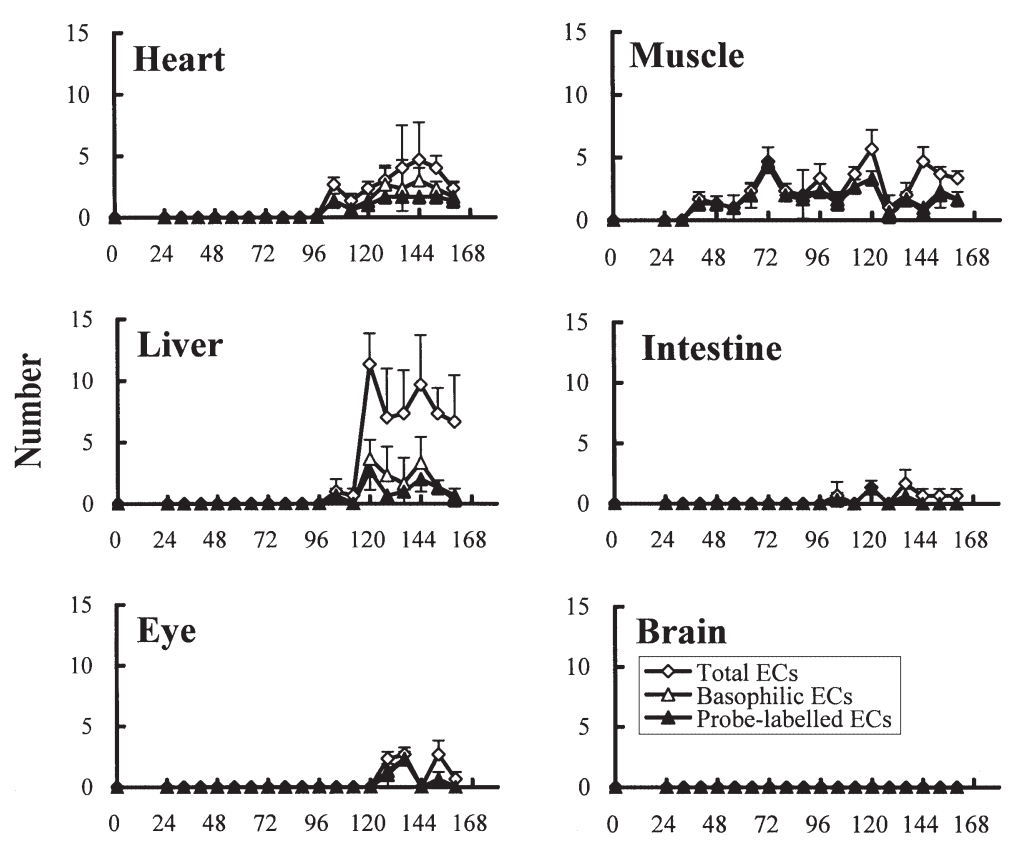

Time (h)

Fig. 5. Epinephelus hybrid. Kinetics of total enlarged cells, basophilic enlarged cells, and enlarged cells labeled by in situ hybridization in heart, muscle, liver, intestine, eye, and brain during the course of TGIV infection.

Data are cell counts in a $500 \times 500 \mu \mathrm{m}$ area. EC: enlarged cell 
sues, e.g. the renal tubule epithelium, were not affected. In the gills, enlarged cells appeared at $88 \mathrm{~h}$ p.i. These cells moved through the secondary lamella and sometimes blocked the capillary. At $144 \mathrm{~h}$ p.i., numerous enlarged cells were present in the secondary lamella. The blockage of capillaries led to hyperplasia of the gill epithelium and sometimes lamellar fusion. In the liver, swelling degeneration and varying degrees of fatty changes were observed in the hepatocytes at $72 \mathrm{~h}$ p.i. Perivascular cuffing of mononuclear cells was noticed around the hepatic vein. At 104 h p.i., a few enlarged cells, both basophilic and eosinophilic, were seen in the hepatic sinosoids, but the endothelium was unaffected. After 112 h p.i., both basophilic and eosinophilic enlarged cells appeared in the sinosoids and the hepatic vein, with significant cuffing of the hepatic vein by mononuclear cells.

Myofibrillar disruption with focal myocarditis, and the presence of basophilic enlarged cells were observed in the ventricle after $104 \mathrm{~h}$ p.i. Less severe inflammation was seen in the bulbus arteriosus. A few enlarged cells distributed among the elastic fibers and sometimes the breaking of elastic fibers and mononuclear cell infiltration were observed. Enlarged cells in the intestines and the eyes were rare, and most were within the blood vessels. We did not find enlarged cells in the brains.

Electron microscopic examination of enlarged cells in the spleen $64 \mathrm{~h}$ p.i. revealed various degrees of abnormality (Fig. 6). Mitochondria were swollen, with disintegration of the cristae, a situation that occurs when cells are stressed. The nuclei increased significantly in size, some reaching 7 to $8 \mu \mathrm{m}$ in diameter. Heterochromatin aggregated on one side of the nuclei. In some cells, inclusion bodies could be seen inside the cell. Regions of different electron density were identified in the heterochromatin. Light micrography (Fig. 3A) revealed that the cytoplasm was basophilic, and the DNA probe concentrated in the nucleus.

At $72 \mathrm{~h}$ p.i., many enlarged cells in the spleen had mature virions in their cytoplasm (Fig. 7). Light micrography (Fig. 3B) revealed that both the basophilic cytoplasm and the nucleus (when visible) were labeled by the DNA probe. In these cells (whether with or without virions) we observed swollen mitochondria, an increased number of primary lysosomes, and a welldeveloped endoplasmic reticulum. In those cells with virions, the nucleus could not always be identified. In cells without virions, a double membrane-bound inclusion body and heterochromatin of different electron densities were sometimes found.

Rupture of the nuclear membrane could be a possible mechanism releasing viral DNA into the cytoplasm (Fig. 7). Progression from the nucleus with a partially ruptured nuclear membrane to the viromatrix with a remnant nuclear membrane was observed. Electrondense material, possibly of viral origin, was located inside the nuclei near the rupture site. During examination, enlarged cells with virions never had an identifiable nucleus. The viroplasm generally occupied a large proportion of the cytoplasm. Inside the viroplasm, virus particles were assembled around either a ring-shaped or a disc-shaped virogenic stroma (Fig. 8) Multiple virions could be assembled the same time, and the newly assembled virions did not have electron-dense material in their center. It is likely that only the capsid was constructed in the virogenic stroma. The centers of the newly formed virus particles were either electron-translucent or had granular materials with electron density similar to that of the virogenic stroma.

Many incomplete virus particles, in a 'dot-in-circle' conformation, were seen in the viroplasma. The electron-dense material in these particles was much smaller and less dense than in mature virions. Short bullet-shaped structures, with an electron density similar to the electron-dense material in the 'dot-in-circle' virions, were frequently found in the viroplasm. It is speculated that these bullet-shaped structures could be inserted into assembled capsids to form the 'dot-incircle' virions or mature virions. Unidentified tubular structures, possibly aberrant forms of the virus, were visible in the viroplasm. The proposed sequence of virus assembly is shown in Fig. 9.

At 120 h p.i., enlarged cells exhibiting marked lytic changes or containing intracellular electron-dense debris were dominant in the spleen and kidney. Light micrography (Fig. 3C) showed that the eosinophilic enlarged cells at this stage $(120 \mathrm{~h}$ p.i.) contained a granular cytoplasm with the nuclei displaced to one side. After 144 h p.i., enlarged cells containing electron-dense debris were found in high numbers in the gills (Fig. 10), possibly representing residual bodies derived from necrotic cells. Myelin figures, honeycomb-like structures, and sometimes remnant nuclei were identified.

Some structures were seen less frequently in sections (Fig. 11). We observed 2 types of inclusion body inside the nuclei: the first type was homogeneously granular in appearance with an electron density higher than that of the cytoplasm and chromatin, and was not membrane-bound (Fig. 11A: a). The second type was bound by a double-layered membrane (Fig. 11A: b). Although similar, the electron density of the second type was slightly higher than that of the cytoplasm, and therefore unlikely to be an invagination of the cytoplasm. Paracrystaline arrays were not observed in the tissue of challenged fish, but in natural infected fish a large array of virions were visible in the 

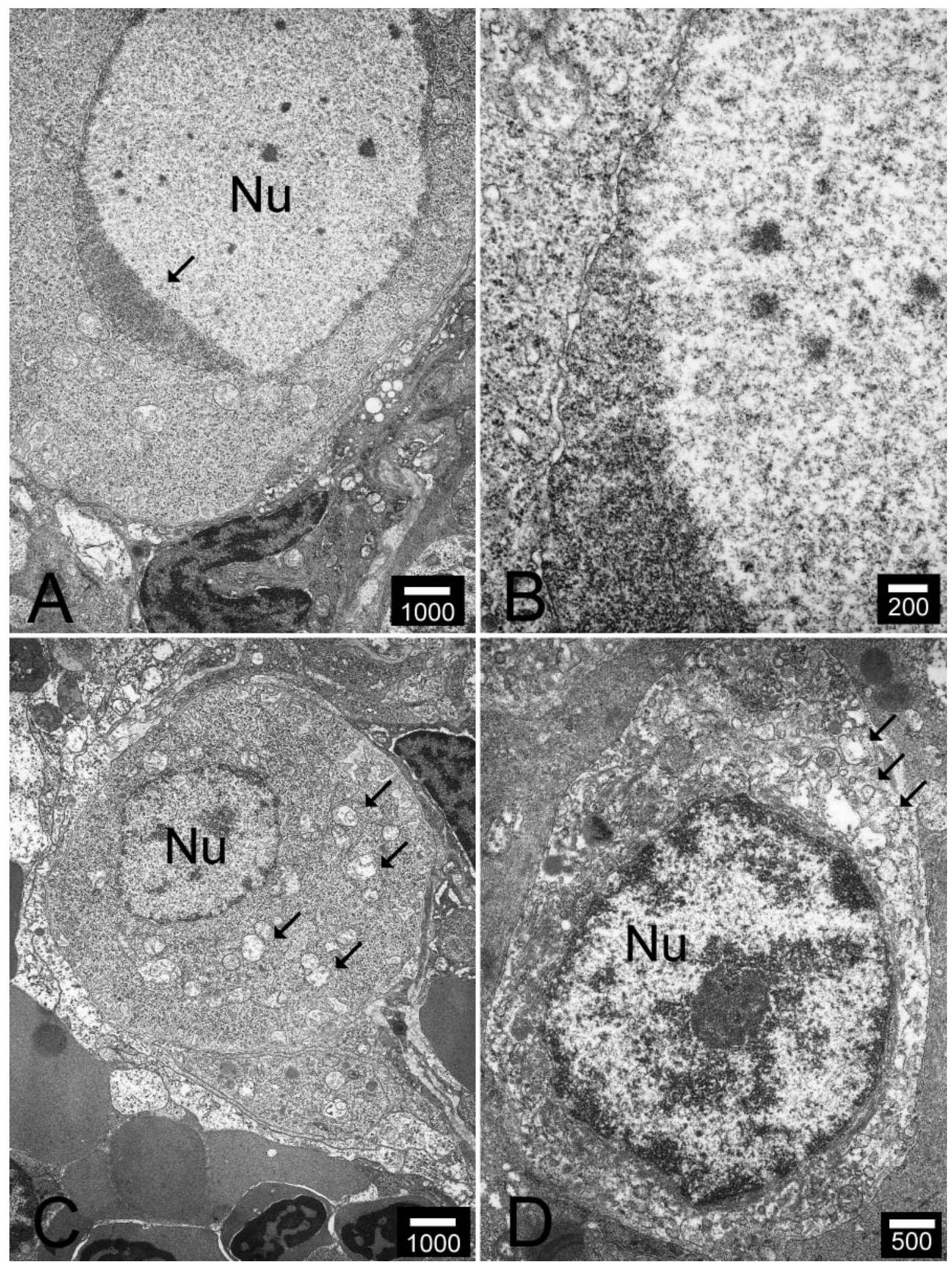

Fig. 6. Epinephelus hybrid. Ultrastructural changes in enlarged cells in spleen $64 \mathrm{~h}$ after the TGIV challenge. (A) Heterochromatin (arrow) is present on one side of the nucleus $(\mathrm{Nu})$ and lines inner nuclear membrane; note enlarged nucleus (diam. $>10 \mu \mathrm{m}$ ). (B) High magnification of (A). (C) Mitochondria (arrows) are swollen and degenerated. (D) Severe degeneration of mitochrondria (arrows) has occurred. Nucleolus is visible inside the nucleus. Scale bars in $\mathrm{nm}$ 


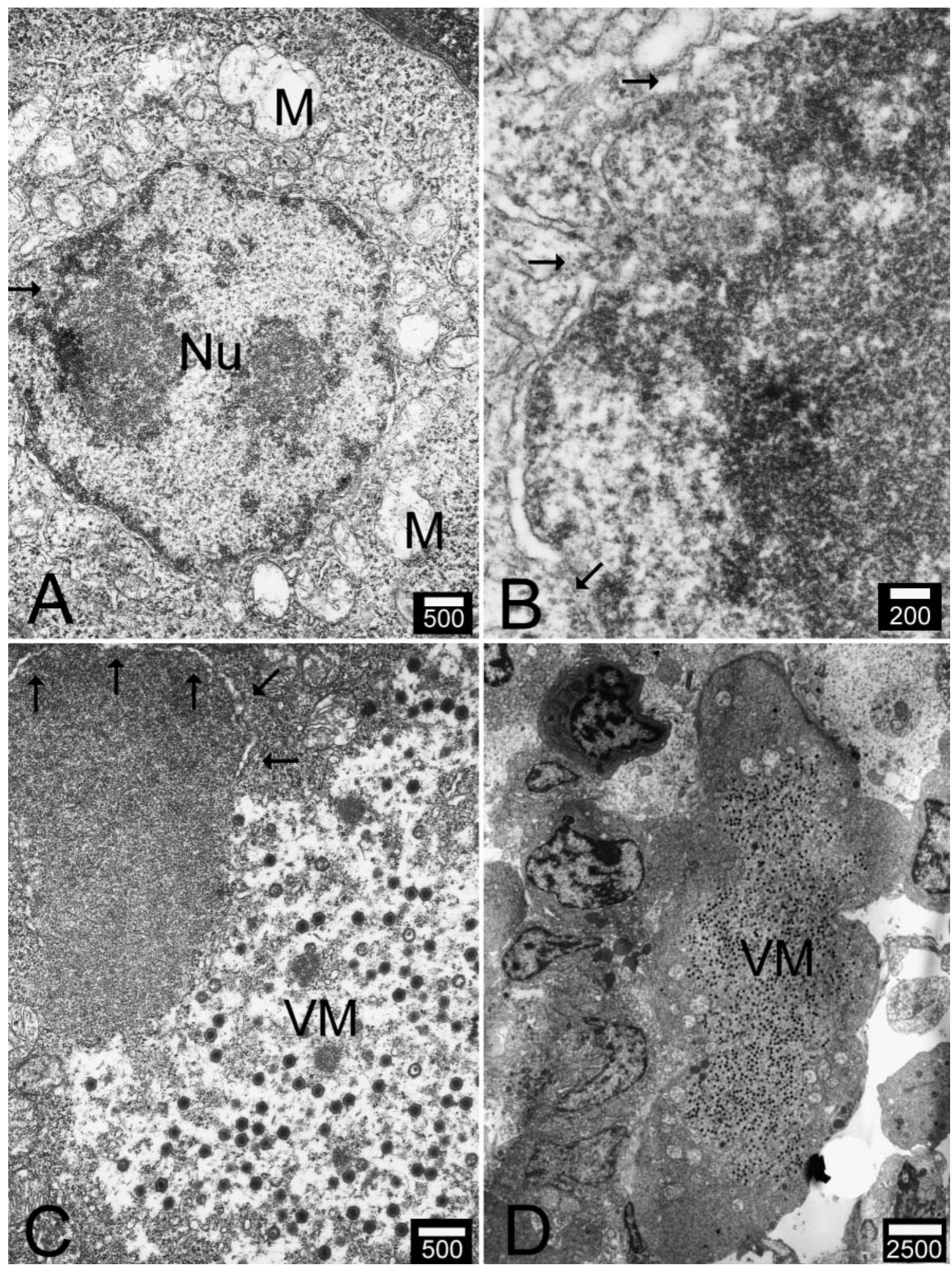

Fig. 7. Epinephelus hybrid. Ultrastructural changes in enlarged cells in spleen. (A), (B) 72 h p.i., showing enlarged cells with degenerated mitochondria (M) and ruptured nucleus (NU), and electron-dense material, possibly of viral origin; rupture of nuclear membrane (arrowhead) could be a possible mechanism for releasing TGIV DNA into the cytoplasm. (C) $72 \mathrm{~h}$ p.i., showing disintegration of nuclei and formation of viromatrix (VM); note remaining nuclear membrane (arrows). (D) $136 \mathrm{~h}$ p.i., showing viromatrix (VM) surrounded by many distended mitochondria; nucleus is not visible, a typical characteristic of infected cells; this cell is apparently larger than those around it, an increased number of endosomes was seen in enlarged cells. Scale bars in nm 

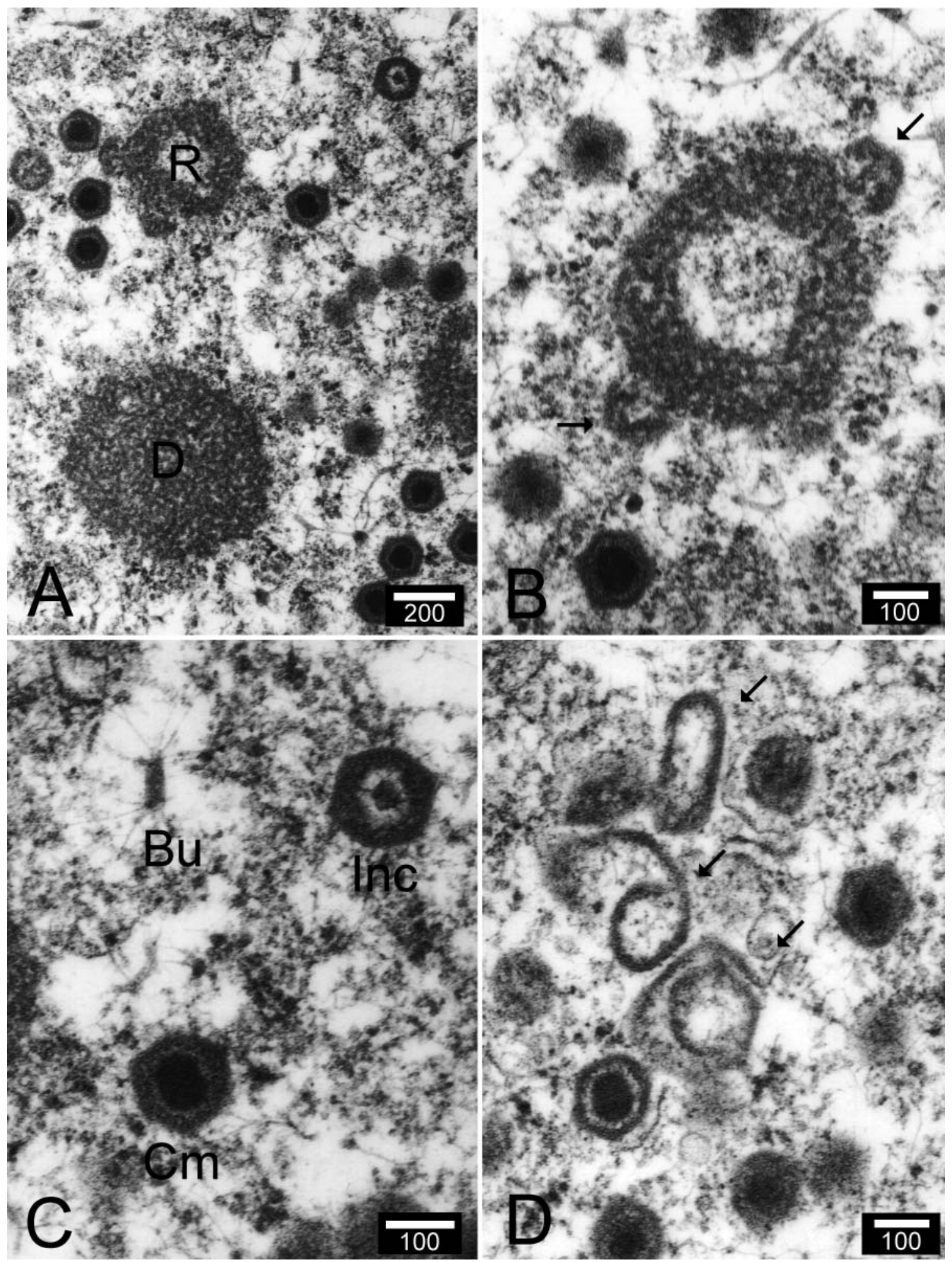

Fig. 8. Epinephelus hybrid. TGIV assembly in viromatrix inside enlarged cells, in the spleen at $72 \mathrm{~h}$ p.i. (A) Assembly apparatus can be either ring-shaped (R) or disc-shaped (D). (B) High magnification of ring-shaped virogenic stroma, with new virus particles being assembled (arrows). (C) Complete $(\mathrm{Cm})$ and incomplete (Inc) virus particles in viroplasm; electron-dense bulletshaped materials $(\mathrm{Bu})$ usually appeared near incomplete virus particles and are thought to be part of the virus. (D) Unidentified tubular structures (arrows) that may be aberrant forms of the virus. Scale bars in $\mathrm{nm}$ 


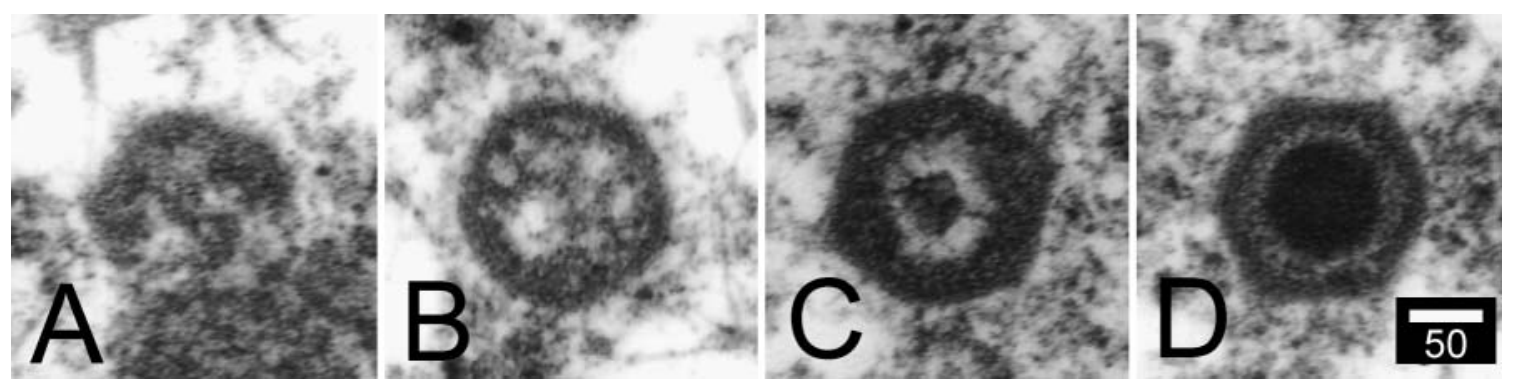

Fig. 9. TGIV. Proposed sequential steps of virus assembly. (A) Capsid assembled from either ring-shaped or disc-shaped assembly site. (B) Newly assembled capsid containing granular material; note that the granular material has an electron density similar to that of the assembly site. (C) 'Dot-in-circle' conformation with increased electron density in center. (D) Complete virion, with electron-dense core. Scale bar in nm

cytoplasm (Fig. 11C). In some instances we did observe virions taken up inside the lysosome (Fig. 11D). Virions inside the lysosome showed various degrees of degradation and were possibly in the process of releasing nucleic acid into the host cell. A 4-layer structure of the partially degraded capsid could be discerned (Fig. 11D).

Control groupers were not labeled, and therefore did not show any positive signal in their tissues after in situ hybridization or PCR. All groupers in the control group were healthy and survived the experiments.

\section{DISCUSSION}

Enlarged cells have been reported in many confirmed iridovirus infections of fishes. The earliest report was for red sea bream (RSIV; Inouye et al. 1992), in which enlarged cells with basophilic cytoplasm were found in the spleen, heart, kidney, liver, and gill. From the morphology and localization of these cells, they were considered leukocytes. Similar viruses have been described for a number of fishes including ALIV from African lampeye, GIV from grouper Epinephelus malabaricus, SBIV from sea bass (Miyata et al. 1997), an RSIV-like iridovirus from striped beakperch Oplegnathus fasciatus (Jung \& Oh 2000, Kim et al. 2002), and ISKNV from the mandarinfish Siniperca chuatsi (He et al. 2001). These viruses were proposed to form a separate taxonomic unit, and were collectively termed 'cell hypertrophy iridoviruses' (He et al. 2001). Phylogenetic trees derived from major capsid proteins, cytosine DNA methyltransferase, ATPase, and DNA polymerase suggest that these viruses differ from other iridoviruses. The ATPase gene (this study) and the CY15 fragment (GenBank Accession No. AF462341; Chao et al. 2002) sequences of TGIV we obtained are identical to ISKNV, and have over $90 \%$ similarity to the RSIV group. It is likely that all these viruses originated from a common ancestor and should be considered a single species, with the RSIV group as a subspecies and TGIV with ISKNV as a further subspecies. The earliest TGIV-infected grouper was received in our laboratory around 1980, preceding the discovery of ISKNV. Whether TGIV and ISKNV were derived from the same common origin, or whether TGIV simply spread from the grouper (a saltwater fish) to the mandarin fish (a freshwater fish), remains an interesting question to pursue in the future.

Enlarged cells have also been found in other unidentified fish iridoviruses or iridovirus-like agent infections. Bloch \& Larsen (1993) described a systemic infection in cultured turbot, in which, the virusinfected cells occluded the capillary in the secondary lamella. They described 2 types of infected cells: the first type had a region referred to as a 'light matrix' that often displaced the nucleus; the second type contained a large dark inclusion resembling a residual body and had few or no virions. These 2 types may correspond to the basophilic and eosinophilic enlarged cells we observed. However, in turbot, the nucleus and viromatrix were present in infected cells simultaneously. Similar infections have been described in the chromide cichlid Etroplus maculatus (Armstrong \& Ferguson 1989), tilapia Oreochromis niloticus (McGrogan et al. 1998), and the freshwater angelfish Pterophyllum scalare (Rodger et al. 1997). None of these viruses were further characterized or isolated, and therefore comparison is not possible. However, it suggests that the host range and prevalence of these 'cell hypertrophy iridoviruses' may be much broader than at present thought.

Chou et al. (1998) successfully isolated TGIV with the KRE cell line, but the virus infectivity declined dramatically during serial passages. Since no fish cell line can provide a replicable source of TGIV, the time necessary to obtain the maximal number of viruses through purification from infected tissues is of paramount importance. Although pathological changes were prominent after $144 \mathrm{~h}$ p.i., the in situ hybridiza- 

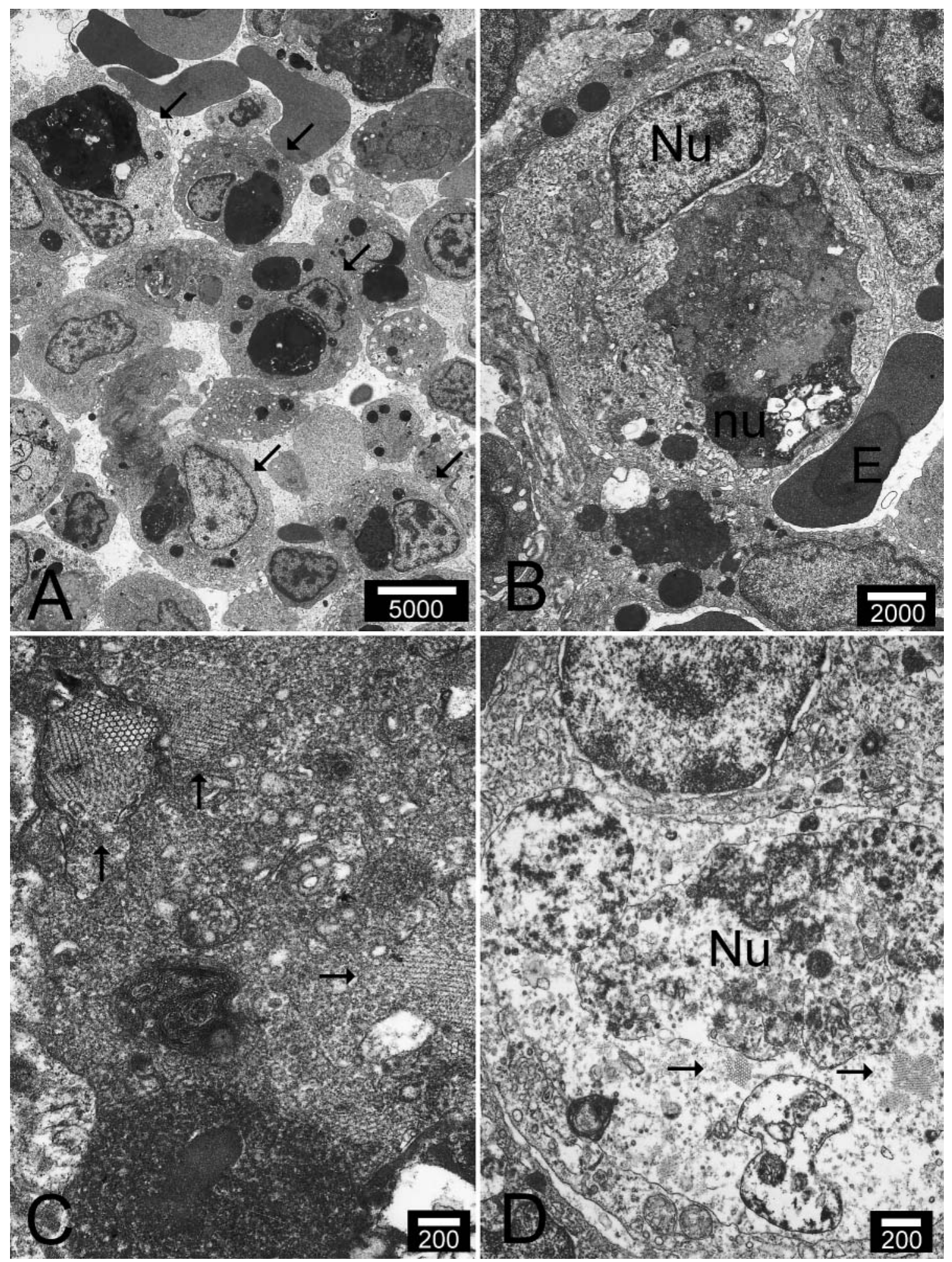

Fig. 10. Epinephelus hybrid. Enlarged cells in gills at $144 \mathrm{~h} \mathrm{p.i;} \mathrm{at} \mathrm{this} \mathrm{time} \mathrm{most} \mathrm{enlarged} \mathrm{cells} \mathrm{were} \mathrm{eosinophilic} \mathrm{in} \mathrm{hematoxylin}$ and eosin stain. (A) Many enlarged cells (arrows) are visible containing intracellular electron-dense cell debris. (B) Enlarged cell is much larger than erythrocyte $(\mathrm{E})$; a structure inside debris is possibly nucleus $(\mathrm{Nu})$ of the dead cell. nu: nucleus of phagocytosed cell (C). Honeycomb-like structures (arrows are visible inside phagocytosed debris). (D) Some enlarged cells with severe lytic changes; nucleus $(\mathrm{Nu})$ has begun to disintegrate; these cells also have a honeycomb-like structure (arrows) similar to that of the phagocytosed necrotic cell in (C). Scale bars in $\mathrm{nm}$ 

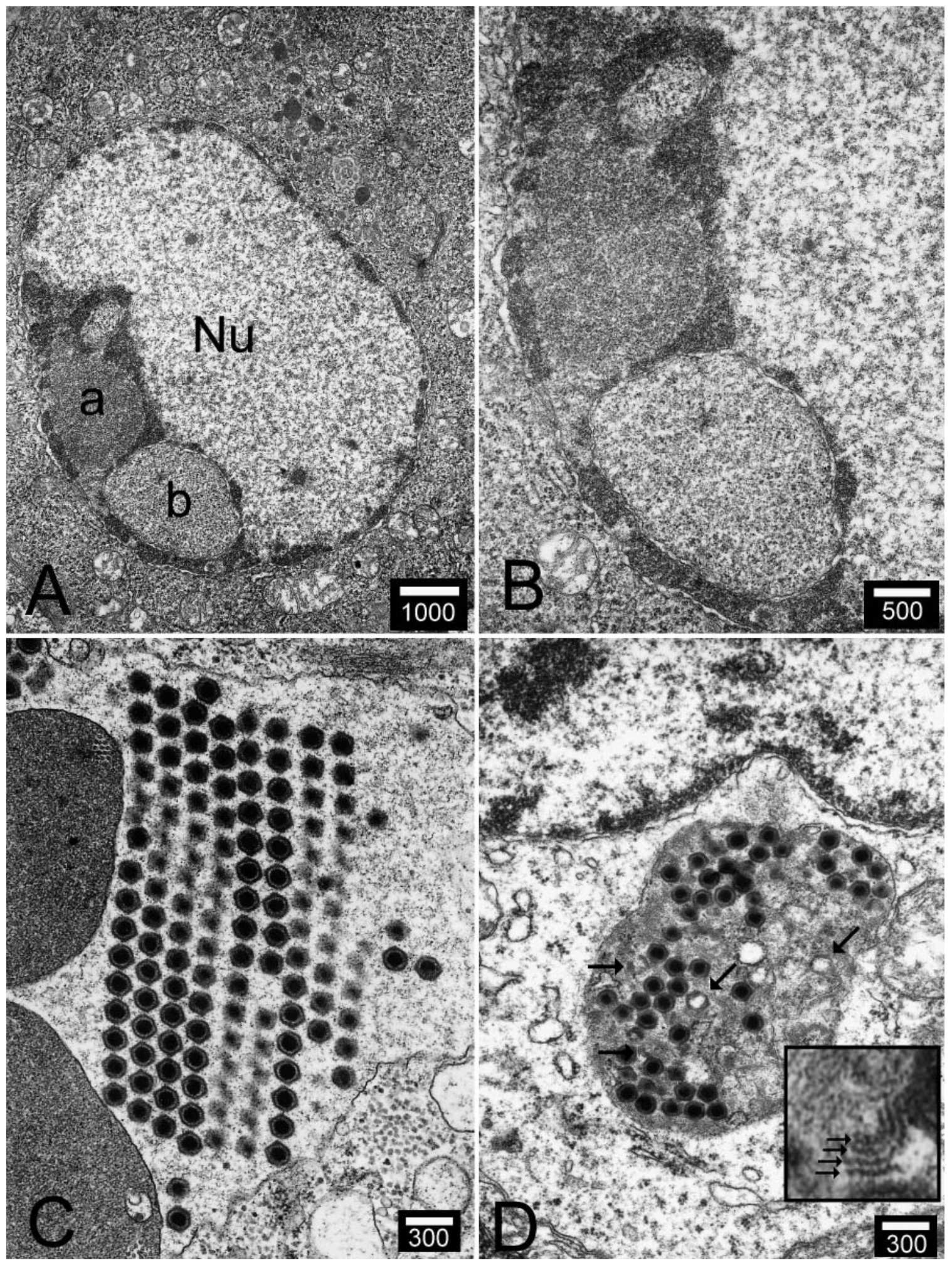

Fig. 11. Epinephelus hybrid. Pathology of TGIV-infected fish. (A, B) Inclusion body inside nucleus (Nu) of an infected spleen cell at $72 \mathrm{~h}$ p.i; inclusion body (a) is surrounded by heterochromatin; an unknown compartment (b) is speculated to be invaginated cytoplasm, but has a slightly higher electron density than the cytoplasm. (C) Paracrystaline array inside enlarged cells (seen only with natural, not artificial, infection). (D) Virus particles within lysosome-like vesicle; capsids of some particles are particularly degraded (arrows) and may release nucleic acid into the host cell; 4-layer structures are clearly visible (insert, arrows). 
tion result indicated that few virus-containing cells were present in the tissues. Our observation under TEM also confirmed that only a few virus-containing cells were present in the gill in the later stages (after 5 d p.i.). In support of this, experience with artificial challenges has shown us that emulsions prepared from fish during the late stage of infection sometimes failed to cause infection in naïve hosts. Therefore, gills of infected fish contain only a low number of virus-containing cells and are not suitable for preparing the virus; instead, the spleen, trunk kidney, and head kidney should be used. As basophilic enlarged cells appear first in the spleen, this should be used for early screening of TGIV infection.

Several iridovirus infections have been reported in the genus Epinephelus. The sleepy grouper disease virus (SGDV) was described in the brown spotted grouper E. tauvina (Chua et al. 1994), and was related to FV3 according to its major capsid protein amino acid sequence (Qin et al. 2003). Histologically, no enlarged cells were found in the tissues. Ultrastructurally, SGDV formed a central cytoplasmic viromatrix and displaced the nucleus; this was not seen in TGIV infection. Also, the insertion of striped electron-dense material into empty capsids (Qin et al. 2001) was different from our observation for TGIV. Another iridovirus closely related to FV3 was also isolated from yellow grouper $E$. awoara in Taiwan (Murali et al. 2002). The high similarity between the available gene sequences from TGIV and ISKNV, and the low similarity between the MCP sequences of either SGDV or the yellow grouper iridovirus to ISKNV, suggest that these iridoviruses are different from TGIV. Since the yellow grouper iridovirus and TGIV were collected from the same geographical region, the epidemiology and prevalence of both viruses are important issues to be clarified in the future. Another grouper iridovirus, isolated from $E$. macabaricus (GIV, Miyata et al. 1997) was reported in Thailand. This virus was closely related to RSIV and was molecularly clustered with other 'cell hypertrophy iridoviruses' (He et al. 2001). ATPase gene-sequence analysis (Fig. 1) indicated that GIV and TGIV are closely related but cluster in distinct groups.

The in situ hybridization technique using the CY15 probe proved to be a specific method for demonstrating TGIV-infected cells. Only the basophilic enlarged cells were labeled, and neither the eosinophilic enlarged cells nor any other cell type in the same fish was labeled. Electron microscopic (EM) observations supported this. When basophilic enlarged cells were dominant, many virus-containing cells were found under EM; when eosinophilic enlarged cells were dominant, their main ultrastructural feature was large cytoplasmic, possibly phagocytosed, necrotic cells. The in situ hybridization results also showed that, during the early stage (64 h p.i.), viral DNA was present only in the nuclei of infected cells (Fig. 3A), while in later stages the probe labeled both nuclei and cytoplasms (Fig. 3B,C). Research with Frog Virus 3 has shown that this virus has a unique 2-stage replication mechanism, the first replication occurs in the nucleus, and the replicated viral DNA is then transported to the cytoplasm for a second-stage replication (Goorha 1982). TGIV may have a similar replication mechanism.

The ultrastructural morphology of the iridovirusinfected cells and the viral morphogenesis have been described for RSIV and related fish viruses, CIV (Iridovirus), FV3 (Ranavirus), white sturgeon iridovirus (WSIV), and some unclassified iridoviruses. After entering the host cell, the virus particles were found inside electron-dense lysosome-like vesicles in CIV (Mathieson \& Lee 1981) and FV3 (Braunwald et al. 1985). In TGIV-infected cells, virus particles could also be found inside vesicles. The extensive microtubule formation and cytoplasmic inclusions seen in FV3infected cells (Kelly \& Atkinson 1975) were not found in TGIV-infected cells. The distribution of chromatin in a TGIV-infected cell is different from that in an FV3infected cell, and is not arranged along the inner nuclear membrane as with FV3 (Kelly 1975). Although the pathology of WSIV infection includes cell hypertrophy, it does not reach the same extent as in TGIV infection (Watson et al. 1998). Also, the unique ultrastructural feature, the concentrically arranged double-unit membrane structure in the viral assembly site of WSIV (Watson et al. 1998), was not seen in TGIV-infected fish. In RSIV-infected red sea bream, enlarged cells contain prominent inclusion bodies and are described as 'inclusion body bearing cells (IBCs)' (Jung et al. 1997). Similar findings were reported for other related viral infections in other species, including ALIV, DGIV, SBIV and grouper spawner disease iridovirus, GSDIV by Sudthongkong et al. (2002a,b). In accordance with the terminology of these authors, we use the designation 'tropical iridoviruses' to describe these viruses. Early-stage IBCs were basophilic, hypertrophied and contained small inclusion bodies; mature IBCs contained an entirely basophilic cytoplasm due to the presence of enlarged inclusion bodies. Ballooning, degenerated IBCs were rounded and eosinophilic, and contained expanded inclusion bodies with a granular appearance under the light microscope; they were electron-lucent, with few virions visible under the electron microscope, and presented degenerated organelles. High similarity was observed between cells infected by TGIV and those infected by tropical iridoviruses. However, in contrast to tropical iridovirus-infected cells, in TGIV-infected cells there is no apparent slit or membranous structure separating the viromatrix from the cytoplasm as sometimes seen 
in tropical virus infections (Sudthongkong et al. $2002 b)$. The nuclei of TGIV-infected cells disintegrated before the viromatrix was fully established in the cytoplasm; however, the nuclei was displaced to one side in tropical iridovirus-infected cells, even when the inclusion bodies occupied most of the cytoplasm (Jung et al. 1997, Sudthongkong et al. 2002a,b). The most striking difference is that the eosinophilic enlarged cells in tropical iridovirus infections are ballooning, degenerated cells with few remaining virions in their inclusion bodies, while in TGIV-infected cells all the eosinophilic enlarged cells observed were phagocytes containing cell debris. Since the high DNA sequence similarity suggests a close relationship between tropical iridoviruses and TGIV, it would be interesting to resolve the apparent difference in the pathology caused by these viruses and explore the underlying pathogenesis.

ASFV is a macrophage-infecting virus in pigs with the characteristics of both iridovirus and poxvirus. After experimental ASFV infection of pigs, Sierra et al. (1987) reported degeneration and necrosis of Kupffer cells and hepatocytes. They described hypertrophic Kupffer cells containing large amounts of vacuolar cytoplasm with a similar morphology to the basophilic enlarged cells that we observed. Interestingly, the number of these cells increased during the course of the infection but declined at $7 \mathrm{~d}$ p.i., similar to the kinetics of the basophilic enlarged cells in our study. However, in TGIV-infected cells, no extensive microtubules or intermediate filaments were found inside or near the viral assembly site, as reported for ASFV (Carvalho et al. 1988).

Devauchelle (1977) described the ultrastructure and morphogenesis of an iridovirus (Nereis iridescent virus, NIV, or Iridovirus Type 27, IV27) infecting the marine worm Nereis diversicolor. The virion size $(180 \times$ $160 \mathrm{~nm}$ ) was similar to TGIV. Virogenic areas similar to the ring-shaped (Devauchelle 1977) and disc-shaped (Darcy \& Devauchelle 1987) virogenic stroma in TGIVinfected cells have only been discovered in this virus. Unfortunately no further study of this virus is available, but this suggests that a virus similar to TGIV may exist in other marine invertebrates, or even that TGIV could utilize marine invertebrates as natural reservoirs.

Several papers have indicated that iridoviruses can influence the performance of immune cells in fishes. Siwicki et al. (1999) indicated that sheatfish iridovirus had a strong suppressive influence on the respiratory burst of pronephric macrophages and mitogenesis of pronephric lymphocyte in sheatfish. Essbauer \& Ahne (2002) reported that EHNV-induced apoptosis in EPC (Epithelioma papillosum cyprini) cells $12 \mathrm{~h}$ after infection. In the electron micrographs we present in this study, no sign of apoptosis is visible in the enlarged cells. Therefore, the cytomegaly is not a direct result of iridovirus-induced apoptosis.

To sum up, the pathogenesis of TGIV may begin with a first replication in the spleen before $64 \mathrm{~h}$ p.i., resulting in an increased number of basophilic enlarged cells in the spleen. The viruses released from these infected cells spread to other organs, possibly by infected phagocytes or simply through the circulatory system. The replication of viruses in other organs, especially the trunk kidney and head kidney, lead to a second peak in basophilic enlarged cells around $120 \mathrm{~h}$ p.i. During this time, the necrotic cells increase in number and macrophages appear to remove the necrotic cells. After the second peak, the host either mounts an effective defense to prevent further virus replication, or the depletion in susceptible cell types results in a gradual decrease in the number of basophilic enlarged cells. The increase in eosinophilic enlarged cells is due either to the removal of more necrotic cells or another, unknown, viral mechanism. A consequence of the presence of enlarged cells in the circulatory system, these cells are trapped in the capillaries, especially in the gills, resulting in insufficient gas exchange and finally in the death of the fish.

Acknowlegements. The authors want to express their sincere thanks to Dr. Wolfgang Volgelbein and Dr. Han-Chen Ho for their invaluable contribution to the electron micrograph analysis, Dr. Rodman G. Getchell for a critical review of the manuscript, and Mr. Chih-Tuan Tang for technical assistance with electron microscopy.

\section{LITERATURE CITED}

Armstrong RD, Ferguson HW (1989) Systemic viral disease of the chromide cichlid Etroplud maculatus. Dis Aquat Org 7: 155-157

Bloch B, Larsen JL (1993) An iridovirus-like agent associlated with systemic infection in cultured turbot Scophthalmus maximus fry in Denmark. Dis Aquat Org 15:235-240

Braunwald J, Nonnenmacher H, Tripier-Darcy F (1985) Ultrastructural and biochemical study of Frog Virus 3 uptake by BHK-21 cells. J Gen Virol 66:283-293

Carvalho ZG, Alves De Matos AP, Rodrigues-Pousada C (1988) Association of African swine fever virus with the cytoskeleton. Virus Res 11:175-192

Chang PS, Lo CF, Wang YC, Koh GH (1996) Identification of white spot syndrome associated baculovirus (WSBV) target organs in shrimp, Penaeidus monodon, by in situ hybridization. Dis Aquat Org 27:131-139

Chao CB, Pang VF (1997) An outbreak of an iridovirus-like infection in cultured grouper (Epinephelus spp.) in Taiwan. J Chin Soc Vet Sci 23:411-422

Chao CB, Yang SC, Tsai HY, Chen CY, Lin CS, Huang HT (2002) A nested PCR for the detection of grouper iridovirus in Taiwan (TGIV) in cultured hybrid grouper, giant seaperch and largemouth bass. J Aquat Anim Health 14: 104-113

Chou HY, Hsu CC, Peng TY (1998) Isolation and characterization of a pathogenic iridovirus from cultured grouper 
(Epinephelus sp.) in Taiwan. Fish Pathol 33:201-206

Chua FHC, Ng ML, Ng KL, Loo IJ, Wee JY (1994) Investigation of outbreak of a novel disease, 'sleepy grouper disease', affecting the brown spotted grouper, Epinephelus tauvina Forskal. J Fish Dis 17:417-427

Darcy F, Devauchelle G (1987) Chapter 25. Iridoviridae. In: Nermut MV, Steven AC (eds) Animal virus structure. Elsevier Science, New York, p 407-420

Devauchelle G (1977) Ultrastructural characterization of an iridovirus from the marine worm Nereis diversicolor (O. F. Müller). Virology 81:237-246

Essbauer S, Ahne W (2002) The epizootic haematopoietic necrosis virus (Iridoviridae) induces apoptosis in vitro. J Vet Med Ser B 49:25-30

Goorha R (1982) Frog virus 3 DNA replication occurs in two stages. J Virology 43:519-528

He JG, Wang SP, Zeng K, Huang ZJ, Chan SM (2000) Systemic disease caused by an iridovirus-like agent in cultured mandarinfish, Siniperca chuatsi (Basilewsky), in China. J Fish Dis 23:219-222

He JG, Deng M, Weng SP, Li Z, Zhou SY, Long QX, Wang XZ, Chan SM (2001) Complete genome analysis of the mandarin fish infectious spleen and kidney necrosis iridovirus. Virology 291:126-139

Inouye K, Yamano K, Maeno Y, Nakajima K, Matsuoka M, Wada Y, Sorimachi M (1992) Iridovirus infection of cultured red sea bream, Pagrus major. Fish Pathol 27:19-27

Jung SJ, Oh MJ (2000) Iridovirus-like infection associated with high mortalities of striped beakperch, Oplegnathus fasciatus (Temminck et Schlegel), in southern coastal areas of the Korean peninsula. J Fish Dis 23:223-226

Jung SJ, Miyazaki T, Miyata M, Danayadol Y, Tanaka S (1997) Pathogenicity of iridovirus from Japan and Thailand for the red sea bream Pagrus major. Fish Sci 63: $735-740$

Kelly DC (1975) Frog virus 3 replication: electron microscope observations on the sequence of infection in chick embryo fibroblasts. J Gen Virology 26:71-86

Kelly DC, Atkinson MA (1975) Frog Virus 3 replication: electron microscope observations on the terminal stages of infection in chronically infected cell cultures. J Gen Virology 28:391-407

Kim YJ, Jung SJ, Choi TJ, Kim HR, Rajendran KV, Oh MJ (2002) PCR amplification and sequence analysis of iridolike virus infecting fish in Korea. J Fish Dis 25:121-124

Kurita J, Nakajima K, Hirono I, Aoki T (1998) Polymerase chain reaction (PCR) amplification of DNA of red sea bream iridovirus (RSIV). Fish Pathol 33:17-23

Li PC, Huang HT, Liang JT (2001) Neurophysiological effects of recurrent laryngeal and thoracic vagus nerves on mediating the neurogenic inflammation of the trachea, bronchi, and esophagus of rat. Autonom Neurosci Basic Clin 88: 142-150

Mathieson WB, Lee PE (1981) Cytology and autoradiography

Editorial responsibility: Jo-Ann Leong,

Kaneohe, Hawaii, USA of Tipula iridescent virus infection of insect suspension cell cultures. J Ultrastruct Res 74:59-68

McGrogan DG, Ostland VE, Byrne PJ, Ferguson HW (1998) Systemic disease involving an iridovirus-like agent in cultured tilapia, Oreochomis niloticus L. - a case report. J Fish Dis 21:149-152

Miyata M, Matsuno K, Jung SJ, Danayadol Y, Miyazaki T (1997) Genetic similarity of iridoviruses from Japan and Thailand. J Fish Dis 20:127-134

Murali S, Wu MF, Guo IC, Chen SC, Yang HW, Chang CY (2002) Molecular characterization and pathogenicity of a grouper iridovirus (GIV) from yellow grouper, Epinephelus awoara (Temminck \& Schlegel). J Fish Dis 25:91-100

Nuove GJ, Darfler MM, Imparaim CC, Bromley SE (1991) Occurrence of multiple types of human papillomavirus in genital tract lesions: analysis by in situ hybridization and the polymerase chain reaction. Am J Pathol 58:518-523

Qin QW, Lam TJ, Sin YM, Shen H, Chang SF, Ngoh GH, Chen CL (2001) Electron microscopic observations of a marine fish iridovirus isolated from brown-spotted grouper, Epinephelus tauvina. J Virology Methods 98: $17-24$

Qin QW, Chang SF, Ngoh-Lim GH, Gibson-Kueh S, Shi C, Lam TJ (2003) Characterization of a novel ranavirus isolated from grouper Epinephelus tauvina. Dis Aquat Org 53:1-9

Rodger HD, Kobs M, Macartney A, Freichs GN (1997) Systemic iridovirus infecion in freshwater angelfish, Pterophyllum scalare (Lichtenstein). J Fish Dis 20:69-72

Sierra MA, Bernabe A, Mozos E, Mendez A, Jover A (1987) Ultrastructure of the liver in pigs with experimental African swine fever. Vet Pathol 24:460-462

Siwicki AK, Pozet F, Morand M, Volatier C, Terech-Majewska E (1999) Effects of iridovirus-like agent on the cell-mediated immunity in sheatfish (Silurus glanis) - an in vitro study. Virus Res 63:115-119

Sudthongkong C, Miyata M, Miyazaki T (2002a) Iridovirus disease in two ornamental tropical freshwater fishes: African lampeye and dwarf gourami. Dis Aquat Org 48: 163-173

Sudthongkong C, Miyata M, Miyazaki T (2002b) Viral DNA sequences of genes encoding the ATPase and the major capsid protein of tropical iridovirus isolates which are pathogenic to fishes in Japan, south China sea and Southeast Asian countries. Arch Virol 147:2089-2109

Thompson JD, Gibson TJ, Plewniak F, Jeanmougin F, Higgins DG (1997) The ClustalX windows interface: flexible strategies for multiple sequence alignment aided by quality analysis tools. Nucleic Acids Res 24:4876-4882

Watson LR, Groff JM, Hedrick RP (1998) Replication and pathogenesis of white sturgeon iridovirus (WSIV) in experimentally infected white sturgeon Acipenser transmontanus juveniles and sturgeon cell lines. Dis Aquat Org $32: 173-184$

Submitted: January 15, 2003; Accepted: September 12, 2003 Proofs received from author(s): January 19, 2004 